https://doi.org/10.7250/scee.2021.0008

\title{
DIFFERENT MODELS OF CAREER REINVENTION AND RETOOLING IN THE POST-PANDEMIC ERA
}

\section{Lukman RAIMI}

\author{
Universiti Brunei Darussalam, Brunei, Darussalam
}

Corresponding author e-mail: Luq_man2001@yahoo.com

\begin{abstract}
To contribute to human capital development in readiness for the Postpandemic era, this paper discusses different models of reinvention/retooling as a resilience strategy in the face of vulnerabilities in the labour market. Using a critical literature review (CLR), this paper discusses different models of career reinvention/retooling, including the imperatives in the Post-pandemic era. At the end of the CLR, three insights emerged. First, the twelve (12) different models of career reinvention/retooling in readiness for the Post-pandemic era are task, position, knowledge, occupation, expertise, technical skills, attitude, brand/value, conceptual skills, competencies, managerial skills and entrepreneurial skills. Second, the different models of career reinvention/retooling are imperative because of environmental factors such as economic recession, pandemic/epidemic organisational downsizing, outsourcing, change management, mergers \& acquisitions, the emergence of new technologies, globalisation waves, demographic shifts, climate change, migration, and disruptive business models in the labour market, among others. Third, career reinvention/retooling requires tripartite collaboration from critical stakeholders, particularly governments, employees, and business organisations. The paper concludes with policy, managerial and theoretical implications, and suggestions for future research.
\end{abstract}

Keywords: Career reinvention, Retooling, Human capital development, Post-pandemic Era, Models.

JEL Classification: A11, A20, C67, D02, D51, D78, E24, F44, G01, H12

\section{INTRODUCTION}

Globally, the COVID-19 pandemic has destroyed jobs, rendering several skills obsolete - a situation that calls for a pragmatic adaptation of skills and competencies to help employees and employers come to grips with the new realities (Osland et al., 2020). In the midst of the mixed effects of the crisis, some proactive companies are already rethinking and reinventing their business models and embracing career reinvention/retooling in the face of the uncertainty caused by the pandemic (Kilic \& Marin, 2020). For instance, a tailoring factory in Argentina reinvented operations at the peak of COVID-19, from sewing police uniforms to the production of surgical masks. Surgical masks prevent infection and safeguard economic operations (Duff, 2020). Similarly, the largest printing presses in Latin America retooled the machines and reinvented operations from book publishing to the production of $3 \mathrm{D}$ protective masks and hand sanitisers (Duff, 2020). However, lagging companies are counting business 
losses and waiting for external interventions in the face of frightening and scary statistics on the pandemic!

In addition, reliable reports have indicated that the pandemic has reduced the demand for jobs with low levels of education by $40 \%$ in Australia and the United Kingdom, whereas the preference for highly skilled workers has increased by $25 \%$ (OECD, 2021). Similarly, the new norm of working from home (WFH) has become pervasive in Australia, Canada, New Zealand, the United Kingdom, and the United States (OECD, 2021). For low-skilled employees and vulnerable workers, retraining and upskilling are urgent to foster and accelerate the development of the required competencies and skills (Chopra-McGowan \& Reddy, 2021). Consequently, it has become normal to dispense with employees in the pandemic ear through permanent layoff, temporary layoff, voluntary temporary layoff and suspension of non-essential recruitments (University of Washington, 2021).

The International Labour Organisation/ILO (2021a) reported an unprecedented disruption of the labour market by the pandemic. The COVID-19 pandemic disrupted businesses and heightened massive job losses in some sectors and led to a reduction in the workforce in several others (Raimi, 2021). It brought working hours in the 4th quarter of 2020 down by 8.8 percent, which corresponds to 255 million full-time jobs (ILO, 2021a). Most of the companies are laying off, but those actively employing and expanding business operations are those in the logistics, health, medicine, retailing sectors (Lane, 2021).

The objective of this paper is to discuss the different models of career reinvention and retooling in the Post Pandemic Era, the roles of stakeholders and the reasons why both strategies are expedient. In specific terms, the paper provides answers to three research questions (RQ): (a) What are the different models of career reinvention/retooling and outcomes? (b) What are the roles of stakeholders in career reinvention/retooling? and (c) Why is career reinvention/retooling imperative?

\section{METHODS AND APPROACH}

A qualitative research method - an interpretivist paradigm - was adopted. The required primary data were sourced from scholarly articles, working papers, text, and online line resources. The critical literature review (CLR) was used to analyse the insightful information in the sourced primary data. The process entails analysing several articles, texts, and working papers based on a content-oriented criterion following a three-stage protocol highlighted below:

i. Stage 1: Data sourcing - Exploration of academic databases for articles from which over 70 relevant articles were selected purposively.

ii. Stage 2: Data development and conversion - Compilation of articles on career reinvention and retooling in readiness for analysis data.

iii. Stage 3: Data analysis - The articles were critiqued, critically appraised, and analysed, and insightful findings were reported (Croom et al., 2000; Jepson, 2009; Saunders \& Rojan, 2011; Soni \& Kodali, 2012). 


\section{LITERATURE REVIEW}

\section{Defining Career Reinvention/Retooling}

Career reinvention is a psychosocial issue that is influenced by internal and external factors that necessitate role adjustments (Watts et al., 2015; Walker, 2019). The solution to job loss and redundancy caused by the pandemic is to adopt a career reinvention strategy. Years back, Henry Mintzberg (1987) posited that strategy reinvents itself as Five-Ps, namely, Plan, Ploy, Position, Pattern, and Perspective.

Therefore, career reinvention could also be described as a reskilling pathway for millions of unemployed global workforces (Chopra-McGowan \& Reddy, 2021). Moreover, it also refers to an occupational change and psychological transition that requires taking up a completely new role and set of tasks (Ibarra, 2004; Walker, 2019). In addition, career reinvention is inevitable in periods of economic recession and environmental crisis because jobs are destroyed and cherished careers are lost. A scholar asked a pertinent question and provided the needed answer: "How can one design a career when career as an institution is dead? Entrepreneurs have an answer." (Denning, 2002). In the strategy literature, one of the resilient maxims for coping with economic recessions and environmental crises is "Tough times never last, but tough people do" (Nair, 2014).

From the foregoing quotes, career reinvention represents a deliberate work change, which takes the forms of a task change, a position change, and an occupation change and all three forms lead to a completely new role and set of tasks (Heppner, 1998; Walker, 2019). Other scholars of career development described career reinventing using synonyms such as career reimagining (Burns, 2015), career reinventing' (Ibarra, 2004), career recrafting' (Mintzberg, 1987), career reorienting (Bridges, 2004), career reframing (Brown, 2015), and renewing' (Wang, Olsen \& Shulz, 2013).

With regard to career retooling, the literature describes it as an initiative to obtain training, education, and cutting-edge skills for the purpose of growing in a profession (Boese, 2006). The process of career retooling demands commitment because it takes at least one year, but two years are the most ideal (Kreeger, 2000). Furthermore, career retooling connotes acquiring a unique kind of aptitude, specialised training, expertise, and new knowledge in certain professions for the purpose of meeting the needs of a growing labour market (Katz et al., 2009). Rutgers Continuing Studies (2021) describes career retooling as updating skills to re-enter the workforce or launch a new career.

\section{Perspectives on COVID-19 Pandemic}

In the literature, there are two perspectives on crises, public health crises, environmental crises, and economic recessions, namely, vulnerability and resilience perspectives (Raimi \& Manishimwe, 2021). The insights from both perspectives are explained in Figure 1. 

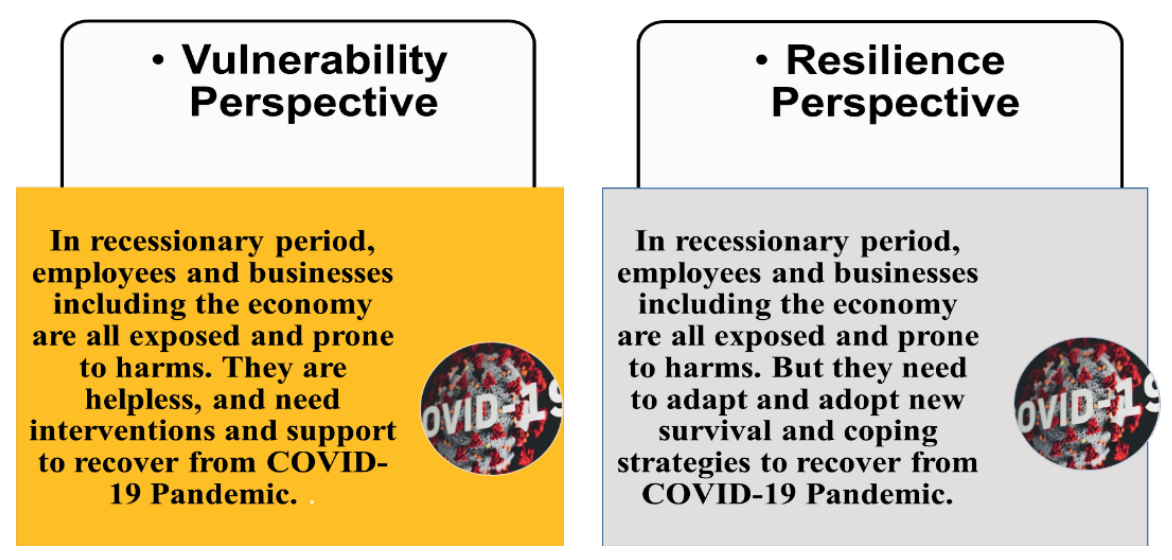

Fig. 1. Review of Literature: Perspectives on COVID-19 Pandemic (developed by the author's adapted from Raimi \& Manishimwe, 2021).

\section{IMPERATIVES OF CAREER REINVENTION/ RETOOLING}

The insights from the CLR indicated that career reinvention/retooling is imperative because of internal and external factors that force role adjustments on employees and employers (Watts et al., 2015; Walker, 2019). Common internal factors include downsizing, organisational deregulation, outsourcing, technological change, and mergers \& acquisitions (Gysbers, Heppner, \& Johnston, 1998; Heppner, 1998). Other internal factors are age, sicknesses, job dissatisfaction, skills obsolescence, changes in features of jobs, demand for social skills, and new workplace lifestyle behaviours.

Moreover, the external factors that drive career reinvention/retooling are the COVID19 pandemic, new technologies, globalisation waves, demographic shifts, climate change imperatives, and migration, recession, newly emerging opportunities in critical sectors of the economy (ILO, 2021b). The highlighted internal and external factors require employees to develop three key competencies in the labour market, namely, critical digital and cognitive capabilities, (b) social and emotional skills, and (c) adaptability and resilience (Agrawal, et al., 2020). Where these key competencies are not forthcoming, alternatives are often inevitable to keep the labour market going. In Slovenia, the Czech Republic, and Slovakia, every thousand workers are to be replaced with two robots (Killc \& Marin, 2020).

Career reinvention/retooling is the best trade-off for saving jobs and ensuring business continuity in the pandemic era, as it would help to save human lives by providing Post-pandemic workplaces with the highly desired workforce with the right knowledge, skills, competencies. Consequently, it would serve as a sustainable human capital development strategy to the existential threat to the planet, people \& profits posed by the pandemic. The foregoing is supported by three cases and global statistics presented below.

The first case is Amazon company, which needs its employees to reinvent careers to cope with the dynamism of the global economy. The management, therefore, implemented proactive workplace career reinvention in early 2019, several months before the COVID-19 pandemic. Amazon committed \$700 million to retrain its 100,000 employees in the US in readiness for 2025 higher-skilled jobs in technology and software engineering (Bloomberg, 2019). When the pandemic struck, the leadership of Amazon expanded its career reinvention scope to support 29 million 
people across the world upscaling and upgraded their tech skills through free cloud computing skills training and AWS-designed programmes by 2025 so that beneficiaries could fit the high-demand occupations in the Post pandemic era (Carlson, 2020).

The second case is JPMorgan Chase company, which made a five-year $\$ 350$ million financial commitment tagged "New Skills at Work investment" before the pandemic. The goal is to upskill the technical skills and competencies of its workforce and non-workforce stakeholders in readiness for future work (JPMorgan Chase, 2019). When the pandemic hit the global landscape, JPMorgan Chase expanded the scope of its upskilling programme. In France alone, it injected over $€ 4.3$ million into the career reinvention and reskilling of young people and long-term unemployed people in vulnerable communities in preparedness for stable, well-paid careers (Business Wire, 2021).

The third case is Walmart, which invested more in cross-training programs as part of its readiness for the Post-pandemic era. For automation, career reinvention, and business continuity, the sum of $\$ 14$ billion was budgeted (Golden, 2020; Tyko, 2021). Consequently, the management retained, retrained, and rewarded the employees during the pandemic, when others were firing and downsizing. The company-led career reinvention strategy extends to acquiring the capabilities to handle new leadership roles in digital workgroups, including skills to work in condensed modular automated warehouses and local fulfilment centres, where Walmart stockpiles pantry items, frozen foods, consumables and electronics for meeting the needs of customers in a changing world (Tyko, 2021).

The fourth case is Brooks Brothers and New Balance organisations that implemented a career reinvention programme to save jobs and boost business continuity in the midst of the pandemic. Thinking differently about laying off and closing down operations, both companies converted the acute shortage of personal protective equipment (PPE) into an economic opportunity. They therefore retool their machines and manufacturing plants and retrain redundant employees to handle the production of surgical masks and gowns for sale to hospitals, clinics, and other users (Jesuthasan et al., 2020; Zavyiboroda, 2021).

The fifth case explicated the exploits of Tesla, Ford, and General Motors. The three automobile companies exhibited enviable lessons on social experiments of the future of work and career reinvention/retooling. At the peak of the pandemic, the demand for cars dropped drastically; hence, they shut down their production plants during the lockdown. In the face of the shortage of ventilators in hospitals and clinics, both companies quickly saw economic opportunities in the situation. Consequently, the three proactive companies retrained their engineers on new skills in response to the rapid changes in technology and market needs and retooled their machines and plants to produce ventilators for hospitals from automobile spare parts and other stored-up components in their factories (Jesuthasan et al., 2020).

\section{Different Models of Career Reinvention/Retooling}

The insights from the reviewed literature on career reinvention/retooling and its imperatives and twelve (12) different career reinvention/retooling models have emerged, as depicted in Figures 2 and 3 below. 


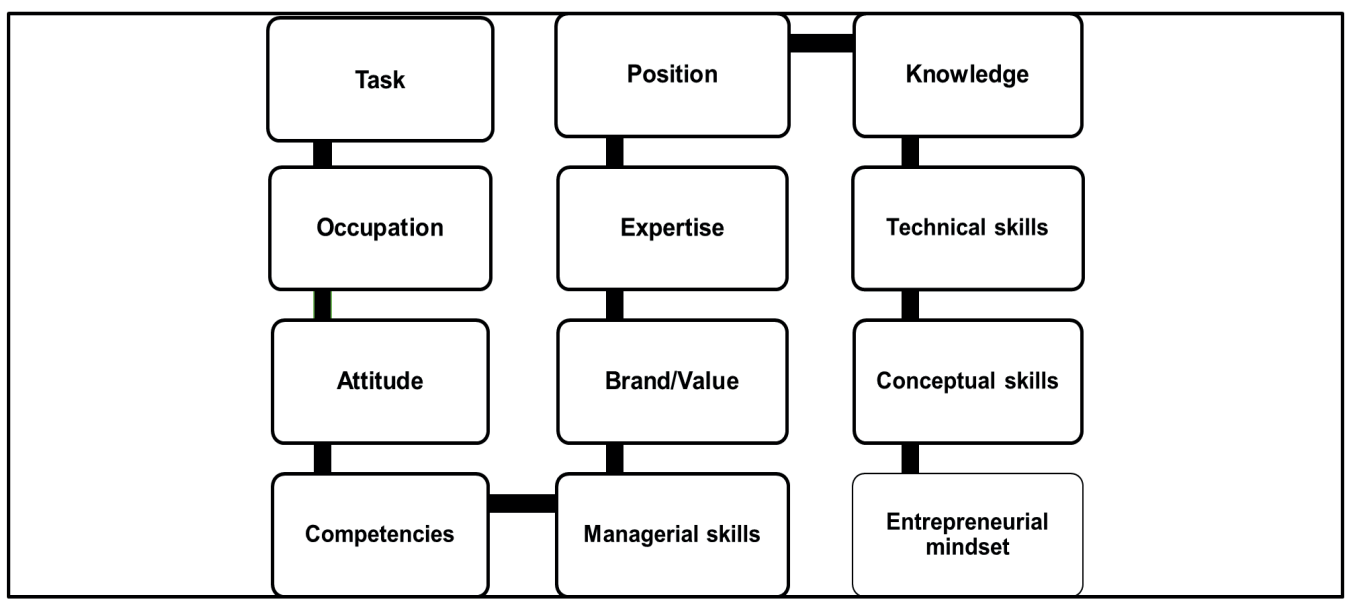

Fig. 2. 12 Models of Career Reinvention/ Retooling (De Vos, 2019; Claus, 2019; Heppner, 1998; Mintzberg, 1978; Omair, 2010; Ibarra, 2004; Walker, 2019).
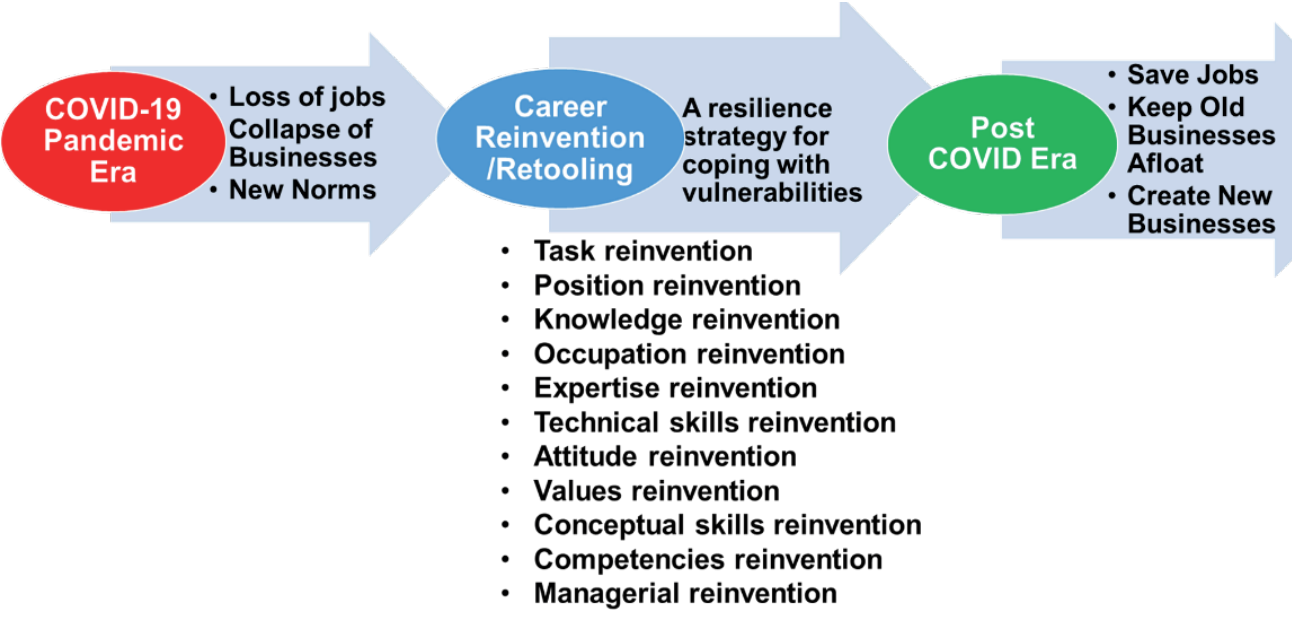

Fig. 3. Career Reinvention/ Retool Fast-tracks Transition from Pandemic Era to PostPandemic Era (developed by the author's).

The 12 different models require different levels of readjustment of task, position, knowledge, occupation, expertise, technical skills, attitudes, brand/value, conceptual skills, competencies, managerial skills, and entrepreneurial skills to meet the needs of future workplaces.

\section{ROLES OF GOVERNMENTS, EMPLOYEES, AND EMPLOYERS}

Career reinvention/retooling requires tripartite collaboration from three critical actors in industrial ecosystems, namely, governments, employers, and employees. The role of governments is to initiate policies to support and accelerate the development of new competencies and skills of citizens to meet the changing needs of labour markets and foster their resilience capabilities. The role of employees is to create personal career paths, embrace self-development, and upgrade themselves as indispensable "brands" for business organisations. The role of employers is to conduct skills inventory and 
need assessment, invest in career reinvention to fill skills and knowledge gaps, remove inhibiting obstacles to employee development and update the skills to cope with technological advances (Agrawal et al., 2020; Castrillon, 2019; Worthington, 2006; ILO, 2021b).

\section{POLICY, MANAGERIAL AND THEORETICAL IMPLICATIONS}

For economic recovery, policymakers need to initiate policies on career reinvention to support citizens' reskilling, upscaling and relearning to meet the changing needs of the labour markets. To save jobs and improve personal wellbeing, employees should embrace career reinvention by upgrading their skills for future jobs. For business continuity and sustainability, managers must invest in career reinvention to fill skills, competencies and knowledge gaps to keep pace with technological advances, foster resilience capabilities, and meet the emerging needs of labour markets. In research, career reinvention connects the two perspectives on recession: It is a resilience tool for coping with vulnerabilities caused by the recession.

\section{REFERENCES}

Agrawal, S., De Smet, A., Lacroix, S., \& Reich, A. (2020). To emerge stronger from the COVID-19 crisis, companies should start reskilling their workforces now. McKinsey Insights.

Boese, K.C. (2006) Career development, or, retooling for a relevant future. The Bottom Line, 19(2). https://doi.org/10.1108/b1.2006.17019baa.001

Business Wire (2021). J.P. Morgan Invests $€ 4.3$ Million in Skills Development for the Young and LongTerm Unemployed in Paris. from https://www.businesswire.com/news/home/20210627005052/en/J.P.-Morgan-Invests-

$\%$ E2\%82\%AC4.3-Million-in-Skills-Development-for-the-Young-and-Long-Term-Unemployed-inParis

Castrillon, C. (2019, November) How To Reinvent Your Career After 40. Forbes.

Carlson, T. (2020, December) Amazon to help 29 million people around the world grow their tech skills with free cloud computing skills training by 2025. Amazon. Retrieved from https://www.aboutamazon.com/news/workplace/amazon-to-help-29-million-people-around-theworld-grow-their-tech-skills-with-free-cloud-computing-skills-training-by-2025

Chopra-McGowan, A. \& Reddy, S. B. (2020, July) COVID-19: How can companies offer effective reskilling for employees? Retrieved from https:/www.weforum.org/agenda/2020/07/reskill-covid19workforce

Claus, L. (2019). HR disruption-Time already to reinvent talent management. BRQ Business Research Quarterly, 22(3), 207-215. https://doi.org/10.1016/j.brq.2019.04.002

Croom, S., Romano, P., \& Giannakis, M. (2000). Supply chain management: an analytical framework for critical literature review. European journal of purchasing \& supply management, 6(1), 67-83. https://doi.org/10.1016/S0969-7012(99)00030-1

De Vos, M. (2019). How the future of work can work for the workers. In Law, Labour and the Humanities (pp. 46-61). Routledge.

Duff, J. (2020, March). COVID-19 Proves Workers Are Essential and Capitalists Are A Drain. Retrieved from https://www.hamptonthink.org/read/covid-19-proves-that-workers-are-essential-andcapitalists-are-a-drain

Golden, R. (2020). Why Walmart is cross-training associates during the pandemic. Publication of HRDIVE. Retrieved from https:/www.hrdive.com/news/why-walmart-is-cross-training-associatesduring-the-pandemic/589201/

Ibarra, H. (2004). Working Identity: Unconventional Strategies for Reinventing Your Career. Boston: Harvard Business School Publishing.

Ibarra, H. (2020, April). Reinventing Your Career in the Time of Coronavirus. Harward Business Review. Retrieved from https://hbr.org/2020/04/reinventing-your-career-in-the-time-of-coronavirus 
International Labour Organisation (2021a, January). ILO Monitor: COVID-19 and the world of work. 7 th edition. Updated estimates and analysis.

International Labour Organisation (2021b). Skilling, upskilling and reskilling of employees, apprentices and interns during the COVID-19 pandemic: Findings from a global survey of enterprises. International Labour Office - Geneva: ILO.

Jepson, D. (2009). Studying leadership at cross-country level: A critical analysis. Leadership, 5(1), 6180. https://doi.org/10.1177/1742715008098310

Jesuthasan, R., Malcolm, T. and Cantrell, S. (2020, April). Crisis Management - How the Coronavirus Crisis Is Redefining Jobs. Harvard Business Review.

JPMorgan Chase (2019). JPMorgan Chase Makes \$350 Million Global Investment in the Future of Work. https://www.jpmorganchase.com/news-stories/jpmorgan-chase-global-investment-in-the-future-ofwork

Katz, P. R., Burton, J. R., Drach, G. W., O'Leary, J. P., Strasser, D. C., Eisner, J. \& Lundebjerg, N. E. (2009). The Jahnigen scholars program: a model for faculty career development. Journal of the American Geriatrics Society, 57(12), 2324-2327. https://doi.org/10.1111/j.1532-5415.2009.02551.x

Kilic, K., \& Marin, D. (2020). How COVID-19 is transforming the world economy. VoxEU. org, 10. Retrieved from https://voxeu.org/article/how-covid-19-transforming-world-economy

Kreeger, K. Y. (2000). Retooling for bioinformatics. The Scientist, 14(23), 35. https://link.gale.com/apps/doc/A68644151/AONE?u=anon afb876b1\&sid=googleScholar\&xid=0a $9 \mathrm{cc} 22 \mathrm{f}$

Mottaeva, A. (2018). Formation of mechanism of programme management for the development of medical organisations. In MATEC Web of Conferences (Vol. 170, p. 01053). EDP Sciences.

Nair, S. D. (2014). Tough times never last, but tough people do. Indian Coconut Journal, 57(3), 6-10.

OECD (2021, April). OECD Policy Responses to Coronavirus (COVID-19) An assessment of the impact of COVID-19 on job and skills demand using online job vacancy data. Retrieved from https://read.oecd-ilibrary.org/view/?ref=1071_1071334-wh692jshet\&title=An-assessment-of-theimpact-of-COVID-19-on-job-and-skills-demand-using-online-job-vacancy-data

Omair, K. (2010), Typology of career development for Arab women managers in the United Arab Emirates. Career Development International, 15(2), 121-143. https://doi.org/10.1108/13620431011040932

Osland, J.S., Mendenhall, M.E., Reiche, B.S., Szkudlarek, B., Bolden, R., Courtice, P., Vaiman, V., Vaiman, M., Lyndgaard, D., Nielsen, K., Terrell, S., Taylor, S., Lee, Y., Stahl, G., Boyacigiller, N., Huesing, T., Miska, C., Zilinskaite, M., Ruiz, L., Shi, H., Bird, A., Soutphommasane, T., Girola, A., Pless, N., Maak, T., Neeley, T., Levy, O., Adler, N. and Maznevski, M. (2020). Perspectives on Global Leadership and the COVID-19 Crisis. Osland, J.S., Szkudlarek, B., Mendenhall, M.E. and Reiche, B.S. (Ed.) Advances in Global Leadership (Advances in Global Leadership, Vol. 13), Emerald Publishing Limited, Bingley, pp. 3-56.

Raimi, L. \& Manishimwe, T. (2021). Small Business Survival of onslaughts of Boko Haram Insurgency, COVID-19 Pandemic and Economic Crisis in Yola, North-East Nigeria: Leveraging Entrepreneurial Marketing. In: Stephens, S. (Ed.). (2022). Cases on Small Business Economics and Development During Economic Crises. IGI Global. http://doi.org/10.4018/978-1-7998-7657-1 .

Rutgers Continuing Studies (2021). Career Retooling. Retrieved from https://lifelonglearning.rutgers.edu/career-retooling

Saunders, M. N. \& Rojon C (2011). On the attributes of a critical literature review. Coaching, 4(2):156162. https://doi.org/10.1080/17521882.2011.596485

Soni, G. \& Kodali, R. (2012). A critical review of empirical research methodology in supply chain management. Journal of Manufacturing Technology Management, 23(6), 753-779. https://doi.org/10.1108/17410381211253326

Tyko, K. (2021). Walmart raising pay for 425,000 workers starting March 13 after strong holiday sales amid COVID-19. USA Today.

Worthington, J. (2012). Reinventing the workplace. Routledge. 


\section{AUTHORS' SHORT BIOGRAPHY}

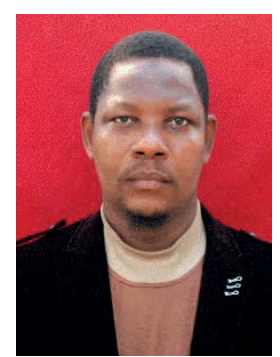

Dr. Lukman Raimi is an Assistant Professor of Entrepreneurship in the School of Business and Economics (SBE), Universiti Brunei Darussalam (UBD). Prior to joining the UBD, he was an Assistant Professor and the Chair of Entrepreneurship at the American University of Nigeria (AUN). Additionally, he was formerly the Coordinator of the Graduate Program in the School of Business \& Entrepreneurship and the Director Centre for Entrepreneurship in AUN. He is an entrepreneurship educator trained at the Entrepreneurship Development Institute (EDI), Ahmedabad, India, under the World Bank-Step B Project. He had specialised training in Enterprise Education for Employability (EEE) at Pan-Atlantic University Nigeria under the British Council's sponsorship. He was an alumnus of the Cumberland Lodge Residential Mentoring (2014), Windsor, United Kingdom. He attended the 2019 Experiential Classroom XX organised for Entrepreneurship Educators at the University of Tampa, Tampa, Florida, United States. He had attended/delivered conferences/seminar papers in Turkey, Malaysia, Ghana, Togo, India, Belfast, Leicester, United States. His publications are listed in Scopus, Researchgate, Publons, and Google Scholar. His research interests include social entrepreneurship, entrepreneurial/digital innovation, medical entrepreneurship, development economics, CSR \& sustainability, SDGs, and family business.

E-mail: Lukman.raimi@ubd.edu.bn

ORCID: http://orcid.org/0000-0002-5329-8715 